\title{
Body Fat Percentage
}

National Cancer Institute

\section{Source}

National Cancer Institute. Body Fat Percentage. NCI Thesaurus. Code C139218.

The amount of an individual's total body mass that is fat, expressed as a percent. 